\title{
Zjawisko „zdrady kontrolowanej” jako przykład kulturowej nienormatywności seksualnej
}

DOI: 10.19195/2083-7763.8.9

W niniejszym tekście będę chciał przedstawić stosunkowo słabo znane zjawisko wśród współczesnych zachowań seksualnych, jakim jest „zdrada kontrolowana” (ang. cuckold). Zdrada kontrolowana jest tu rozumiana jako podejmowanie aktywności seksualnej z innym mężczyzną przez kobietę pozostającą we względnie stałym związku z dotychczasowym partnerem. Warunkiem zdrady kontrolowanej jest wyrażenie zgody lub często wręcz inicjatywy obecnego partnera odnośnie do podejmowania aktywności seksualnej poza związkiem, a niekiedy współobecności partnera podczas zachowania seksualnego kobiety z innym mężczyzną.

Taka praktyka wydaje się zachowaniem seksualnym leżącym poza granicami normatywności. Zdrada seksualna w rozumieniu potocznym jest traktowana jako jedna z najważniejszych przyczyn rozpadu związków. Jednak — jak za chwilę przedstawię - w obliczu gwałtownych przemian seksualności zdrada kontrolowana zyskuje nowe znaczenie i jest sygnałem zachodzących zmian we współczesnym postrzeganiu i doświadczaniu seksualności.

Kultura współczesna jest wypełniona treściami cielesnymi i seksualnymi. Wielu autorów (np. Giddens 2006) zauważa, że współcześnie obserwujemy gwałtowną zmianę rozumienia i zachowań dotyczących seksualności. Mass media dostarczają przekazu, który zarówno tworzy i wspiera, jak i odbija zachodzące zmiany. Popularność treści o charakterze seksualnym, podkreślających ważność tej sfery życia dla współczesnego człowieka, wydaje się niekwestionowana. Codzienne porady na temat rozwoju i urozmaicenia życia seksualnego, sekstaśmy celebrytów, obnażane seksualnie ciała - to jedna strona przekazu. Inną jest tajemniczy świat perwersji, budzący lęk, odrazę czy powszechne potępienie. Ujawnianie siatek pedofilskich, homoseksualne parady równości z występami 
drag quuen, kluby gejowskie i darkroomy, przedstawienia relacji BDSM przenikające do kina popularnego (np. 50 twarzy Greya) spotykają się często z paniką moralną (Zielińska 2015). Taka reakcja jest funkcjonalną próbą przywrócenia ładu społecznego dotyczącego sfery seksualnej współczesnych społeczeństw. Wielość nowych zjawisk seksualnych rodzi chaos interpretacyjny i skutkuje katastroficznymi tezami o upadku kultury i cywilizacji Zachodu.

\section{Kultury seksualne współczesności}

Na zachodzące zmiany można spojrzeć z perspektywy przemian seksualności oraz wiedzy, która daje podstawę interpretacyjną do zrozumienia różnorodności współczesnych obrazów zachowań seksualnych. Chciałbym zatem, w imię uporządkowania, wskazać na współistnienie w kulturze Zachodu trzech „kultur seksualnych”, rywalizujących z sobą o miano dostarczania „prawdy”.

Najstarszą kulturą seksualną dostępną w dyskursie potocznym jest kultura, której zręby opierają się na uzasadnieniach płynących z zasad religii chrześcijańskiej. Wielu autorów (m.in. Brown 2006) wskazuje na pierwotną dla chrześcijaństwa nieufność wobec seksualności. Napięcie pomiędzy negatywnym wartościowaniem zachowań seksualnych a ryzykiem rozpusty oraz koniecznością panowania nad seksualnymi impulsami oraz potrzebą reprodukcji społecznej doprowadziło do wytworzenia dwóch instytucji organizujących seksualność, wspieranych przez Kościół katolicki. Pierwszą z nich, zdaniem Tina (2013), było życie konsekrowane, prowadzone w zakonach oraz w ramach święceń kapłańskich w związku ze złożonymi ślubami czystości i powstałej później reguły celibatu. Drugą instytucją stał się związek małżeński, który dopiero w XVI wieku decyzją soboru trydenckiego stał się powszechnie przyjętym sakramentem.

Podejmowanie aktywności seksualnej w ramach związku małżeńskiego jest jedyną formą aktywności seksualnej, którą dopuszcza Kościół katolicki. W dodatku zarówno mężczyzna, jak i kobieta podczas aktu seksualnego mają do odegrania rolę określoną przez Boga i prawo naturalne. Przez dłuższy czas za grzeszne były więc uznawane także zachowania seksualne podejmowane w ramach małżeństwa, których intencją nie była prokreacja. To ona bowiem przez dłuższy czas dawała rękojmię trwania małżeństwa. Brak kontaktu seksualnego pomiędzy małżonkami nadal może stać się przyczyną unieważnienia małżeństwa. Współcześnie życie seksualne małżonków ma jednak służyć już nie tylko prokreacji, lecz także być wyrazem miłości pomiędzy nimi, ma budować więź i bliskość.

Wszystkie zachowania związane z aktywnością seksualną poza związkiem małżeńskim są potępiane. Cudzołóstwo lub nierząd, które to zjawiska mieszczą się w podejmowanej przeze mnie tematyce „zdrady kontrolowanej”, przez wieki były jednoznacznie odrzucane i uznawane na grzech. Dlatego również dzisiaj w ramach tej kultury seksualnej jakiekolwiek nienormatywne praktyki seksualne 
są kategorycznie piętnowane poprzez odwoływanie się do porządku naturalnego i zadań wyznaczonych małżonkom przez Boga.

Takie spojrzenie na zachowania seksualne stoi w zdecydowanej opozycji wobec obecnie najpopularniejszej i najbardziej rozpowszechnionej kultury seksualnej, którą tworzy seksuologia. Powstanie kultury seksuologicznej było związane z oświeceniową wizją świata, zgodnie z którą wszystkie obszary życia człowieka można objąć naukowym poznaniem, interpretacją i wyjaśnieniem. Najważniejszym „odkryciem” tej kultury było zdefiniowanie „seksualności” (Giddens 2006), którą zinterpretowano jako nieświadomą siłę, niezwykle silnie oddziałującą na życie człowieka.

Studia nad ludzką seksualnością doprowadziły do okrycia wielu zjawisk nienormatywnych, takich jak choćby bogaty świat perwersji seksualnych. Idea seksualności i perwersji seksualnych swoją rozwiniętą postać znalazła w psychoanalizie Zygmunta Freuda i doprowadziła do psychiatrycznego pojmowania seksualności człowieka. Seksualność stała się zatem niezależnym obszarem życia psychicznego człowieka, w pełni autonomicznym wobec innych sfer ciała (Foucault 1995). Dostrzeżenie w człowieku zachowań perwersyjnych połączono nie z niemoralnym - jak dotychczas w kulturze religijnej - zachowaniem, ale z patologiczną osobowością. Sny, marzenia, fantazje, wyobrażenia dotychczas niepowiązane ze sferą seksualną, nabrały w ramach tej kultury niedwuznacznej interpretacji. Dalszym efektem postrzegania seksualności jako jednej z najważniejszych sfer życia człowieka stało się określenie normalnej i perwersyjnej „orientacji seksualnej”, która miała wyrażać prawdziwą seksualną naturę człowieka jako bytu biologicznego.

Psychiatria, a w późniejszym okresie seksuologia szczególnie zainteresowała się odmiennością zachowań seksualnych, szczegółowo je katalogując i podejmując próby rozmaitych interpretacji oraz leczenia. Pierwotnie dużym „powodzeniem” wśród badaczy cieszyło się zjawisko sodomii, z czasem zdefiniowane jako homoseksualizm, a także masturbacja, seksualna histeria, później zaś wiele innych. Warto wskazać, że kultura seksuologiczna miała wbudowaną w swój „naukowy kod genetyczny" wizję emancypacji z kultury religijnej. Stosunkowo szybko zrezygnowano zatem $\mathrm{z}$ oceniania $\mathrm{w}$ kategoriach moralnych nienormatywnych zachowań seksualnych, a zajęto się ich wyjaśnianiem i początkowo także leczeniem. Współcześnie większość nienormatywnych zachowań seksualnych kategoryzowanych jest pod pojęciem „parafilii”. Przykładu wręcz encyklopedycznego katalogowania odmienności zachowań seksualnych dostarcza praca Zbigniewa Lwa-Starowicza Seksuologia sadowa (2000), w której autor podaje, że w seksuologii opisano ponad 200 parafilii, a sam wymienia między innymi takie, jak formikofilia i entomofilia (bodźcem seksualnym są mrówki i insekty), flatufilia (bodźcem jest wzdęty brzuch), siderodromofilia (bodźcem jest wagon pociągu kolejowego) czy sarmassofilia (bodźcem jest ugniatanie mięsa) (Lew-Starowicz 2000). Warto też nadmienić, że według seksuologów większość parafilii dotyczy mężczyzn (Kowalczyk, Ciesielska 2010). 
Prawdopodobnie trudno podać skończoną ilość bodźców seksualnych, należy jednak wskazać, że w dużej mierze mogą się one odnosić do historyczno-społeczno-kulturowego otoczenia człowieka. Prowadzenie jednak tego typu katalogów jest spadkiem po oświeceniowym paradygmacie opisywania i porządkowania biologicznego i społecznego świata otaczającego człowieka.

Najpoważniejszym efektem kultury seksuologicznej było wytworzenie przeseksualizowanej koncepcji człowieka, w której zachowania seksualne uznawane są, szczególnie z powodu popularnonaukowych przekazów kultury masowej i Internetu, za miernik prawidłowego i zdrowego funkcjonowania człowieka (Buczkowski 2016). Przeseksualizowana wizja człowieka prawdopodobnie doprowadziła do powstania tożsamości seksualnej (szczególnie homoseksualnej) oraz zjawiska aseksualności, będącego najpewniej formą obrony przed wszechogarniającym zalewem nakazów podejmowania zachowań seksualnych reprodukowanych w kulturze popularnej.

Seksuologiczne nastawienie do zachowań seksualnych człowieka może być źródłem krytyki. Przede wszystkim przecenia się ważność samego kontaktu seksualnego i orgazmu, który staje się jedynym i najważniejszym miernikiem aktywności seksualnej. Niedawno w seksuologii dostrzeżono też, że zachowania seksualne podejmują nie tylko osoby „w wieku prokreacyjnym”, lecz także na przykład osoby starsze czy niepełnosprawne. Ponadto podczas badania samych zachowań seksualnych seksuolodzy, korzystając z narzędzi socjologicznych, analizują w zasadzie deklaracje zachowań, a nie same zachowania. W obliczu przeseksualizowanych treści kultury popularnej „efekt poprawności” może prowadzić osoby badane do zawyżania swojej aktywności seksualnej lub ukrywania tych jej przejawów, które wydają się nieakceptowane społecznie. W badaniach seksuologicznych zdecydowanie brakuje perspektywy „normalnego” uczestnika zachowań seksualnych, również tych nienormatywnych. Wyniki większości badań (i wywodzone z nich tezy) oparte są na obserwacjach i rozmowach z osobami zgłaszającymi się z problemami seksualnymi lub wręcz ze społecznymi dewiacjami seksualnymi, niekiedy głęboko zaburzonymi, stwarzającymi ryzyko dla siebie i innych.

Wreszcie trzecią kulturą seksualną, najnowszą w sensie historycznym, jest kultura indywidualistyczna, choć w refleksji socjologicznej to nowe definiowanie seksualności nazywa się też niekiedy „seksualnością plastyczną” (Giddens 2006). Charakterystyczną cechą jest tu dostrzeżenie indywidualnego, podmiotowego definiowania aktywności seksualnej oraz interpretacji płynących zeń znaczeń. Głos podmiotu aktywności seksualnej we wcześniejszych kulturach był albo pomijany (kultura religijna), albo formatowany do założonych tez (kultura seksuologiczna). Kultura ta ma wymiar transgresyjny nie tylko w odniesieniu do religijnych norm moralnych, lecz także norm seksuologicznych pomimo emancypacyjnego nastawienia seksuologii. 
Pojawienie się tej kultury jest efektem głębokich przemian społecznych i kulturowych, związanych przede wszystkim z pojęciem intymności, poprawy warunków higienicznych i atomizacji życia w dużych skupiskach miejskich. Możliwość nieskrępowanego doświadczania własnego ciała, zarówno w kontekście higienicznym, jak i innych praktyk okołocielesnych (kosmetyki, sport, dieta, dostosowywanie ciała do wizerunków ciała idealnego, powiązanie cielesności z tożsamością) doprowadziło również do odmiennego doświadczania przeżyć seksualnych.

Możliwość podmiotowego definiowania seksualności została również wsparta przez wynalezienie i rozpowszechnienie pigułki antykoncepcyjnej, która diametralnie zmieniła nastawienie kobiet do zachowań seksualnych. Idea „wolnej miłości” lat siedemdziesiątych XX wieku nie mogłaby pojawić się bez ograniczenia zagrożenia niechcianą ciążą. Zmiany społeczne i medyczne posiłkowały także badania seksuologów oraz popularyzacja ich wyników. Badania Kinseya $(1948,1965)$ oraz Masters i Johnson (1975), a w Polsce Sztuka kochania Michaliny Wisłockiej (1978) zmieniły społeczne postrzeganie zachowań seksualnych. W przekazach popularnonaukowych zaczęto akcentować przyjemność seksualną jako źródło zdrowia, fizycznego, psychicznego, intelektualnego i duchowego dobrostanu, a także wzmacniania więzi emocjonalnych $\mathrm{z}$ partnerem/partnerką.

W perspektywie indywidualnej zachowania seksualne stały się zatem źródłem doświadczeń transgresyjnych, często nieakceptowanych przez seksuologię. Praktyki homoseksualne i masturbacyjne to wybrane przykłady aktywności seksualnej człowieka, w odniesieniu do której seksuologia zmieniła nastawienie z negatywnej na akceptującą. Seksualność staje się powoli projektem indywidualnego kolekcjonowania cielesnych i emocjonalnych doświadczeń, rozwijania fantazji i realizowania pragnień pozwalających na przekraczanie kolejnych kulturowych i społecznych granic. Jeszcze jednym wymiarem zmian dotyczących seksualności jest możliwość upowszechniania przeżyć indywidualnych za pośrednictwem mass mediów, a zwłaszcza Internetu, który daje możliwość wymiany informacji, opinii, doświadczeń oraz kultywowania praktyk seksualnych, o których współczesna seksuologia wypowiada się z dużym dystansem.

Kultura indywidualizowania przeżyć seksualnych i ich intensyfikacji odnajduje także swoje odzwierciedlenie $\mathrm{w}$ rozwoju internetowej pornografii, która zaczęła być już postrzegana jako źródło zmiany społecznej w odniesieniu do roli mężczyzny podczas aktu seksualnego (Zimbardo, Coulombe 2015). Współcześnie wiedza na temat zachowań seksualnych staje się już nie tyle adaptacją popularyzatorskich opracowań seksuologicznych, ile autonomicznym, niekontrolowanym systemem wiedzy niespecjalistycznej, rozpowszechnianej za pośrednictwem Internetu. Jednym z przykładów kultury indywidualizowania seksualności jest „zdrada kontrolowana”, której będę chciał przyjrzeć się bliżej. 


\section{Kulturowe konstrukcje zdrady kontrolowanej — kara i urozmaicenie}

W kontekście kulturowym zjawisko zdrady kontrolowanej było wykorzystywane w kinematografii. Jednym z najbardziej znanych i omawianych przykładów, wywołujących też najwięcej kontrowersji, w którym przedstawione zostało zjawisko zdrady kontrolowanej, był film Larsa von Tiera pod tytułem Przełamując fale z 1996 roku. Obraz prezentuje historię Bess i Jana, młodego małżeństwa żyjącego w Szkocji w latach siedemdziesiątych XX wieku. Religijna Bess, modląc się o powrót swojego świeżo poślubionego męża z pracy na platformie wiertniczej, prosi Boga o jego jak najszybsze przybycie. Jan ulega jednak wypadkowi i staje się częściowo sparaliżowany. Pragnąc Bess, prosi ją, aby odbywała stosunki seksualne $\mathrm{z}$ innymi mężczyznami i opowiadała mu o tym, ponieważ jedynie $\mathrm{w}$ ten sposób może on doświadczyć „zastępczej” satysfakcji seksualnej. Bess, obwiniając się o doprowadzenie do wypadku męża, podejmuje różnorodne, ryzykowne zachowania seksualne i w konsekwencji zostaje zgwałcona i zamordowana w jednej z portowych tawern. Koniec końców Jan w cudowny sposób odzyskuje sprawność w sparaliżowanej części ciała.

Film, niezależnie od kontekstu religijnej winy, kary i odkupienia, porusza obszar zachowań seksualnych nieznany szerszej publiczności, stąd prawdopodobnie kontrowersje, $\mathrm{z}$ którymi spotkał się podczas prezentacji. $\mathrm{W}$ odniesieniu do prezentowanego tematu obraz ten jest ważny, ponieważ najpewniej nasycił lub doprowadził do skanalizowania kulturowych męskich fantazji seksualnych na temat zdrady kontrolowanej. Motyw przekonywania kobiety (żony, partnerki) do podejmowania aktywności seksualnej poza dotychczasową relacją występuje jako istotny wątek, poruszany podczas dyskusji na forum internetowym, które w szerszym zakresie przedstawię w dalszej części opracowania.

Drugi motyw zdrady kontrolowanej pojawia się, wprawdzie epizodycznie, ale w zauważalny sposób, w filmie Romana Polańskiego Gorzkie gody z 1992 roku. Przedstawiono $\mathrm{w}$ nim toksyczną relację pomiędzy amerykańskim małżeństwem - Oskarem i Mimi. Przemoc psychiczna i fizyczna stosowana wcześniej przez mężczyznę doprowadza, w sytuacji częściowej, późniejszej niepełnosprawności fizycznej Oscara, do wymierzania mu przez Mimi różnych „kar”. W jednej ze scen Mimi, w ramach zemsty za wcześniejsze poniżanie i zdrady, odbywa stosunek seksualny z czarnoskórym tancerzem, podczas gdy jej niepełnosprawny mąż, znajdujący się w pokoju obok, przysłuchuje się odgłosom. Film ten prawdopodobnie częściowo przyczynił się do rozpowszechnienia fantazji seksualnej na temat zdrady kontrolowanej jako kary za niewierność lub moralnie nieprawidłowe zachowanie mężczyzny.

Oba wskazane motywy zdrady kontrolowanej — zdrady jako kary dla mężczyzny oraz jako spełnienia męskiego pragnienia dostarczania kobiecie satysfakcji seksualnej - są współcześnie dostępne w dyskursie pornograficznym. Pojawia się tu dodatkowo trzecie rozumienie zdrady kontrolowanej - jako inicjatywa 
kobiety (najczęściej pozostającej w związku), która w ramach urozmaicenia życia seksualnego pragnie kontaktu seksualnego z innym mężczyzną (hasło: femdom cuckold), często czarnoskórym. Może to być pochodna kulturowych wyobrażeń na temat możliwości seksualnych czarnych mężczyzn, co opisał między innymi David M. Friedman (2003). Ten wymiar zjawiska można w pewnym stopniu ująć jako kulturową kobiecą fantazję seksualną, której źródła tkwią w „odkrywaniu” i pozytywnym waloryzowaniu kobiecej seksualności w latach siedemdziesiątych $\mathrm{XX}$ wieku.

W pornografii internetowej motyw zdrady kontrolowanej nie jest najczęściej występującym, ale pełni zauważalną rolę. Na jednym z najbardziej popularnych amerykańskich portali pornograficznych pornhub.com pod hasłem cuckold na początku lutego 2017 roku znajdowało się ponad 4500 filmów pornograficznych. Dla porównania hasło teen ('nastolatka') wywoływało 380 tysięcy filmów, a milf ('atrakcyjna mamuśka') - ponad 150 tysięcy filmów. Zdecydowana większość z nich mieści się w zarysowanych powyżej trzech obszarach dyskursu zdrady kontrolowanej - kary dla partnera w konwencji gry erotycznej, kulturowej męskiej fantazji o przyglądaniu się zdradzie podejmowanej przez kobietę oraz kulturowego kobiecego pragnienia intensywnych przeżyć seksualnych. Większość z zamieszczonych filmów ma charakter amatorski, ich jakość jest słaba. Przeważająca część z nich jest też krótka (w kategorii najczęściej oglądanych średnia długość filmu wynosi około dziesięć-dwanaście minut). Zastosowane obrazowanie jest typowe dla filmów pornograficznych, dominują dwie narracje - narracja voyera, w której obraz jest niekiedy niewyraźny, kamera prowadzona jest w pewnym oddaleniu od filmowanego obiektu (pary), oraz narracja uczestnika, w której pojawiają się zbliżenia na części ciała kobiety (przede wszystkim) oraz mężczyzny.

Niezależnie od akcentowania kobiecej aktywności seksualnej w ramach urozmaicania życia seksualnego dyskurs zdrady kontrolowanej jest prawdopodobnie emanacją kulturowo męskich fantazji. Na portalu pornhub.com bardzo niewiele jest filmów, w których mężczyzna występuje w roli osoby odbywającej stosunek seksualny $\mathrm{z}$ inną kobietą $\mathrm{w}$ obecności partnerki/żony i to zarówno $\mathrm{w}$ odniesieniu do wymiaru kary i wymiaru urozmaicenia, jak i realizacji męskiej fantazji seksualnej akceptowanej przez kobietę. W dyskursie pornograficznym dostępne są filmy pokazujące aktywność dwóch kobiet i jednego mężczyzny, ale nie mają one wymiaru znaczeń przywiązanych ze zdradą kontrolowaną, w której kobieta (żona, partnerka) wyraża zgodę na aktywność seksualną mężczyzny z inną kobietą. W subkulturze zdrady kontrolowanej odwrócona relacja nosi nazwę cockqueen, hasło takie jednak nie występuje na wspomnianym portalu pornograficznym. Dyskurs zdrady kontrolowanej nie jest także prawdopodobnie dostrzegalny w dyskursie osób homoseksualnych. Jest to zatem przykład fantazji realizowanych przede wszystkim w odniesieniu do relacji heteroseksualnej, który może się wiązać z kulturowymi znaczeniami przypisywanymi małżeństwu (lub - współcześnie - stałej relacji heteroseksualnej). 
W dyskursie seksuologicznym zdradę kontrolowaną ocenia się w sposób negatywny. Zbigniew Lew-Starowicz, jeden z najbardziej znanych polskich seksuologów, omawiane zjawisko ujmuje jako „zespół prowokowanej zdrady” i omawia w grupie zaburzeń relacji partnerskich (Lew-Starowicz 2000). Jego zdaniem motywy podejmowania tego typu zachowań są różne i mogą wynikać ze „sprawdzania postawy wierności, tendencji masochistycznych, orgiastycznych, potwierdzania własnej roli seksualnej" (Lew-Starowicz 2000, s. 181). Autor nie wskazuje, kto częściej jest inicjatorem tego typu pragnień (mężczyzna czy kobieta) i zaleca pomoc terapeutyczną oraz „analizę wzajemnych uczuć, zabieganie o stabilność i harmonię związku, a także okazywanie prowokującemu partnerowi, że seks ma wymiar osobowy, nie tylko zmysłowy, i dotyczy więzi z daną osobą" (Lew-Starowicz 2000, s. 182).

Inni specjaliści, szczególnie w kontekście wiedzy popularnonaukowej dystrybuowanej przez mass media, wypowiadają się o zdradzie kontrolowanej jeszcze gorzej. Z perspektywy psychiatry Mai Polikowskiej-Herman uczestnicy zaangażowani w taką relację to osoby o osobowości dyssocjalnej. Przyczyną tego typu zachowań mają być niedobory w zakresie neuroprzekaźników. Po zajściu takiego zdarzenia nie da się już uratować związku (www1).

Podobnie wypowiada się jedna z seksuolożek, Monika Łukasiewicz, w trakcie rozmowy prowadzonej w cyklu „Dobry seks” publikowanej między innymi na stronie internetowej „Gazety Wyborczej”. Jej zdaniem zdrady nie da się kontrolować. W takiej relacji często dochodzi do subtelnej manipulacji, w której jedna ze stron „Zmusza” drugą do akceptacji takich zachowań, a wszystko kończy się zazdrością i innymi negatywnymi emocjami. Jeśli para jest razem bardzo długo, może dochodzić do naturalnego spadku atrakcyjności seksualnej. Ewentualne eksperymenty seksualne mogą być bardzo niebezpieczne, powinny być gruntownie przemyślane, ponieważ nowy partner może być ciekawszy i w większym stopniu spełniać potrzeby seksualne. Pomysł zdrady kontrolowanej ma być wołaniem o pomoc dla związku. Specjalistka seksuologii zaleca w sytuacji wystąpienia tego typu pragnień wizytę u seksuologa lub samodzielną pracę nad urozmaiceniem relacji seksualnej, poprzez wizytę w sex shopie i zaopatrzenie się w gadżety seksualne, wspólne obejrzenie filmu pornograficznego, porozmawianie o własnych fantazjach itp. Warto także zauważyć, że zdrada kontrolowana w wypowiedzi seksuolożki mylona jest ze zjawiskiem „swingersów”, poliamorią i związkiem otwartym (www4). Wydaje się, że żaden z powyższych specjalistów/specjalistek nie zapoznał się nigdy z perspektywą postrzegania tego zjawiska przez osoby w nie zaangażowane.

\section{Rogacze i hotki, czyli zdrada kontrolowana w perspektywie uczestników}

Przykład wspomnianej cechy seksualnej kultury indywidualizacji, jaką jest niespecjalistyczna i transgresyjna dystrybucja wiedzy na temat nienormatywnych zachowań seksualnych, stanowi środowisko osób skupionych wokół portalu cuckold- 
place.pl. Jest to społeczność stosunkowo liczna - na koniec lutego 2017 roku zarejestrowanych użytkowników było ponad 4300 . Warto także podkreślić, że aby zostać użytkownikiem portalu, należy uiścić opłatę w wysokości 39 zł, co dodatkowo selekcjonuje grono do osób bardziej zainteresowanych. Forum działa od 2011 roku i zamieszczone jest na nim ponad 200 tysięcy wpisów. Zawiera informacje na temat perspektywy uczestnika tego typu praktyk i stoi w zdecydowanej sprzeczności z wizjami nakreślonymi przez seksuologię.

Użytkownik forum po zakończeniu rejestracji jest zobowiązany do wyboru preferencji, co jednocześnie wskazuje na podejmowaną rolę w relacji zdrady kontrolowanej, jest też formą zapoznania się ze stosowanym słownictwem. Dla kobiety w tej relacji przewidziana jest rola hot wife, stosowany jest także skrót „hotka”.

Hot Wife czerpie przyjemność z uprawiania seksu z innymi mężczyznami na oczach lub za przyzwoleniem i w obecności swojego partnera. Jest kobietą w związku małżeńskim lub partnerskim, żoną lub partnerką Rogacza. Hot Wife może być również kobietą bez związku, która poszukuje swojego partnera Rogacza. Hot Wife Poszukuje Kochanka, Bulla, większej grupy Kochanków, Bulli lub innej pary lub par, co odbywa się za zgodą oraz wiedzą jej męża lub partnera-Rogacza (www2).

Uczestnicy-mężczyźni relacji zdrady kontrolowanej mogą podejmować jedną z trzech ról: rogacza, bulla lub kochanka (ogiera). Pierwsza z nich jest wyjaśniona na forum w następujący sposób:

Rogacz - Mąż lub partner Hot Wife. Rogacz czerpie przyjemność z oddawania swojej żony lub partnerki innemu mężczyźnie w sposób kontrolowany, za jego zgodą, przy jego aktywnej lub biernej obecności lub zezwala na samodzielne kontakty swojej żony lub partnerki z Kochankami, Bullami lub inną parą lub parami. Może być również samotnym Rogaczem, poszukującym swojej Hot Wife, dzięki której będzie mógł realizować swoje pragnienia dzielenia jej z innym mężczyzną. Rogacz poszukuje Kochanka, Bulla, lub innej pary dla swojej żony lub partnerki. Rogacz może być zarówno hetero, jak i biseksualny, jednak jego kontakty z innymi kobietami, są surowo zabronione przez jego partnerkę $\mathrm{z}$ uwagi na pozycję, jaką zajmuje w związku (www2).

Analogicznie opisane są role „kochanka” oraz „bulla”, który może występować w roli zarówno kochanka, jak i rogacza. Rola kochanka (ogiera) ma zawarte $\mathrm{w}$ sobie ograniczenie, a mianowicie zakaz nawiązywania relacji i propozycji spotkań z hotką, która jest w relacji, bez wiedzy i zgody „rogacza”. Przewidziano za to sankcję usunięcia $\mathrm{z}$ forum.

Dopuszczalny jest też wybór kont dla par: „para cuckold” oraz „para swingers”. W tym miejscu warto zaznaczyć, że istnieje zasadniczy podział pomiędzy kategoriami „swingersów” i „cuckold”. Wyjaśnienie różnicy wskazuje się w objaśnieniu konta dla pary swingersów:

Swingersi preferują przede wszystkim spotkania z radosną wymianą partnerów oraz względnym pominięciem całej trudnej ideologii cuckold. Swingersi poszukują przede wszystkim podobnych do siebie pań i panów, aby wspólnie bawić się seksem w większych grupach (www2). 
Forum dyskusyjne jest niezwykle bogate i zawiera ponad 3000 tematów. $\mathrm{Z}$ perspektywy badacza najistotniejsze będzie poznanie samej struktury forum. Jest ono podzielone na najistotniejsze dla użytkowników tematy (przedstawiam je w kolejności zawartej na forum): „Dyskusje rogaczy, hotwife i kochanków” (ponad 1000 tematów), „Jak rozpocząć realizację fantazji? Wątpliwości na początku” (230 tematów), perspektywa rogacza pod nazwą „Okiem rogacza” (68 tematów), „Damski punkt widzenia” (127 tematów), „Nasze historie prawdziwe” (754 tematów), „Rogate fantazje” (406 tematów), „Opowiadania własne i znalezione w sieci" (673 tematy) ${ }^{1}$. W dalszych podkategoriach można znaleźć galerie i filmy użytkowników, dział nazwany „Zdrowie, uroda i technika”, filmy i zdjęcia z sieci, seks ogłoszenia oraz inne kategorie, takie jak „Ultimate cuckold”, „Bdsm”, „Kobieca dominacja”, „Swingers” oraz „Rozmowy i ciekawostki”.

Nie sposób w tym miejscu poddać analizie wszystkich omawianych tematów, co jest niezwykle interesujące dla poznania perspektywy osób zaangażowanych w zdradę kontrolowaną. Przestawię zatem poglądowo jedynie te tematy, które spotkały się z największym zainteresowaniem i komentarzami uczestników w każdej z wspomnianych kategorii dyskusyjnych.

Same nazwy dyskusji wskazują na obszary znaczące dla opisywanego środowiska. W kategorii „dyskusje rogaczy, hotwife i kochanków” kilka najczęściej poruszanych kwestii dotyczy: zewnętrznych oznaczeń kobiet zaangażowanych w cuckold („Hot wife i łańcuszek na prawej nodze” - 300 odpowiedzi), fantazji seksualnych („Czego jeszcze nie zrobiliście, a chcecie zrobić?” - 292 odpowiedzi, „Ekstremalne rzeczy w seksie” - 282 odpowiedzi, „Marzenia o gwiazdach”, z którymi chciałoby się spędzić noc -247 odpowiedzi), różnic wiekowych pomiędzy partnerami relacji zdrady kontrolowanej („Bardzo młody kochanek, dojrzała kochanka” - 269 odpowiedzi) oraz poziomu „Libido kobiety vs faceci” (236 odpowiedzi), czyli próby podważenia seksuologicznego dogmatu związanego z większym temperamentem seksualnym mężczyzny.

Poruszana tematyka wskazuje na próby określenia materialnego komponentu zbiorowej tożsamości rogaczy i hotek, czym miałby być łańcuszek na nodze, choć zdaniem osób wypowiadających się na forum w Polsce ten zwyczaj nie przyjął się w pełni. Odniesienia do fantazji seksualnych nie dziwią - forum zdrady kontrolowanej jest zbiorowością, która funkcjonuje w obszarze nienormatywnych fantazji i zachowań seksualnych. Relacja między wiekiem hotki i kochanka również wskazuje na zakwestionowanie seksuologicznego założenia o lepszej jakości związku pomiędzy starszym mężczyzną i młodszą kobietą, co zauważalne jest między innymi u Wisłockiej (1978).

Kategoria „Jak rozpocząć realizację fantazji? Wątpliwości na początku” skupia najczęściej porady na temat znalezienia kochanka (176 odpowiedzi), doprowadzenia do relacji trójkąta (100 odpowiedzi) i przejścia od fantazji do jej realizacji

\footnotetext{
${ }^{1}$ Liczba tematów na forum - stan na 28 lutego 2017 roku.
} 
(„Co dalej zrobić, żeby iść na przód?” - 91 odpowiedzi). Warte zauważenia są tematy poruszane przez mężczyzn-rogaczy: „Żona mówi mi, że jest zainteresowana, ale tylko podczas seksu” - 76 odpowiedzi, oraz od "House wife do hot wife” - 62 odpowiedzi. Kwestia męskiej presji i realizacji kulturowo męskich fantazji jest także poruszana na innych grupach dyskusyjnych.

W kategorii dyskusyjnej „Okiem rogacza” pojawiają sięrównież tematy dotyczące fantazji „Na co pozwoliłbyśs swojej hotce?” (161 odpowiedzi), „Myszka pełna spermy kochanka” (159 odpowiedzi). Ważnym zagadnieniem jest także „Wierność rogacza" (138 odpowiedzi). Najciekawszym wątkiem dyskusji wydaje się jednak temat „Cuckold dla bogatych?” (174 odpowiedzi), który wskazuje na miejski oraz klasowy wymiar zjawiska „zdrady kontrolowanej”. Informacje o kosztach spotkań, ze szczególnym uwzględnieniem bezpieczeństwa prywatności, wskazują, że uczestnictwo w tej aktywności jest zarezerwowane dla miejskiej klasy średniej.

Interesującą kategorią dyskusyjną jest „Damski punkt widzenia” (127 tematów). Ta część forum zawiera nie tylko wpisy kobiet, lecz także mężczyzn, choć całość pisana jest $\mathrm{z}$ kobiecej perspektywy postrzegania zdrady kontrolowanej. Nie dziwi najczęściej występujący temat dyskusji: „Najlepsze :) podrywy” (455 odpowiedzi) oraz następne w kolejności w kwestii popularności: temat kobiecego wytrysku „Squirt - dlaczego ze mną nie?” (210 odpowiedzi), „Kryzys męskości? (205 odpowiedzi) czy „Gdzie jest flirt?” (191 odpowiedzi). Najciekawszym, specjalnie wydzielonym wątkiem tej grupy dyskusyjnej jest „Kodeks ogiera”, do którego wpisano tylko 46 odpowiedzi, ale którego wydzielenie z całości wskazuje na charakter normotwórczy w intencji administratorów forum. Kodeks zawiera 39 zasad i jest podzielony na kilka części. Pierwszą część tworzą zasady dotyczące poznania i pierwszego spotkania, na przykład: „1. Zrób wszystko, by na pierwsze umówione spotkanie się stawić. Drugiej szansy możesz nie dostać. 2. Rozpal zmysły hotki przed spotkaniem, łatwiej będzie się dogadać” oraz część dotyczącą przebiegu relacji - podkreśla się, że powinna być prowadzona w konwencji romantycznej:

4. Bądź szarmancki, miły, uprzejmy, kulturalny, zadbaj o swój wygląd, bądź schludny, nie wysyłaj fałszywych zdjęć, stawiaj się na spotkania, słuchaj. [...] 9. Przejawiaj, na wszelkie możliwe sposoby, uwielbienie, jakim darzysz Hotkę. [...] 16. Wykazuj zainteresowanie Hotką nie tylko wtedy, gdy masz ochotę na spotkanie. [...] 22. Pamiętaj, że kobiety zdecydowanie nie są wzrokowcami. Czasami jedno trafne zdanie wypowiedziane do ucha, może wywołać lawinę namiętności. [...] 24. Nie porównuj jej do innych zdobytych przez ciebie kobiet. Traktuj ją jakby była jedyna (www5).

Istotnym wymiarem, który odróżnia spotkanie z hotką od spotkania z kochanką, jest relacja z rogaczem. Część zasad odnosi się właśnie do postępowania $\mathrm{z}$ „trzecią stroną" tej relacji:

28. Traktuj rogacza z należytym szacunkiem, o ile nie zawarliście takiego układu. [...] 29. Nigdy się nie wywyższaj, o ile nie zawarliście takiego układu. [...] 33. Nie bądź samolubny i podczas seksu dbaj o zadowolenie Jej i Rogacza bardziej niż o swoje. 
Relacja zdrady kontrolowanej opiera się na umowie pomiędzy stronami. Wszystkie zachowania powinny być zatem ustalane, na przykład: „12. Bądź szczery sam ze sobą i z parą, z którą się spotykasz, jeśli nie masz na coś ochoty, to po prostu o tym powiedz. 13. Jeśli masz na coś ochotę - proponuj w atmosferze wzajemnego szacunku".

Ponieważ zdrada kontrolowana jako zjawisko nie jest szerzej znana oraz budzi wiele kontrowersji, również w obrębie seksuologii, o czym już wspomniałem, ważnym wymiarem jest zachowanie poufności osób uczestniczących w tej relacji:

18. Nigdy nikomu nie opowiadaj czegoś, co pozwoliłoby na identyfikację Hotki czy pary. Pamiętaj, świat jest mały. 19. Nie rzucaj się na szyję Hotce, gdy spotkasz ją w publicznym miejscu. Teściowa może nie zrozumieć, dlaczego obcy facet obcałowuje jej synową, łapiąc przy tym za tyłek. [...] 26. Nie wypytuj o jej życie prywatne, jeśli sama nie wyrazi chęci na taką rozmowę.

W ten typ relacji wpisane jest również niepowodzenie lub niechęć do jej kontynuowania, do czego odnoszą się następujące zasady:

14. Jeśli nie jesteś zainteresowany kontynuowaniem znajomości, to powiedz to. 14 a. Bądź jednak delikatny i kulturalny. 15. Uszanuj decyzję, iż dana osoba nie jest zainteresowana kontynuacją znajomości. [...] 25. Po zakończonej znajomości nie nękaj jej w jakikolwiek sposób. Koniec to koniec.

Zdrada kontrolowana jest związkiem o dużym stopniu ryzyka dla tradycyjnych relacji małżeńskich. Ryzyko to jest dostrzegane w trakcie dyskusji na forum, w którym pojawia się porównanie fantazji z rzeczywistością. Niekiedy jednak występuje też w oddzielnej kategorii „Dział pożegnań”. Jest w nim niewiele wątków, a najczęściej komentowanym jest post pod tytułem „Stop zabawa” z września 2016 roku. Autor-rogacz opisuje w nim własne doświadczenia związane ze zdradą kontrolowaną, pisze o pierwotnej fascynacji, o późniejszych lękach o fizyczne bezpieczeństwo żony, o jej poszukiwaniach „kochanka na stałe”. Zderzenie fantazji z rzeczywistością okazało się nie tym, czego oczekiwano. Autor wypowiedział zatem hasło ustalone na początku „rogatej przygody” - STOP ZABAWA. Według deklaracji autora od teraz „rogacz i jego pani” biorą się za naprawę swojej relacji, i żegnają się ze wszystkimi użytkownikami forum (www3). Jedna z komentatorek tego wątku napisała: „Fakt jest taki, że o ile z fantazjami miło żyć, to z realnymi doświadczeniami już czasem trudniej, szczególnie jeśli nieprzewidziane i zaskakujące".

\section{Podsumowanie albo zdrada tematu?}

Czego można dowiedzieć się z dość pobieżnego przeglądu tematyki poruszanej na forum cuckoldplace.pl? Z pewnością warto wczytać się dokładniej w treści przekazywane przez uczestników tego zjawiska, co niestety przekracza ramy tego opracowania. W tym miejscu chciałbym jednak zwrócić uwagę na inne wnioski, 
co może być odebrane jako częściowa „zdrada”, to znaczy odejście od tematu, ale zdecydowanie nią nie jest.

Pierwszym z nich jest transgresja i przekroczenie wiedzy płynącej z emancypacyjnego dyskursu seksuologicznego. Zdrada kontrolowana w opiniach seksuologów i innych specjalistów jest zjawiskiem bardzo niebezpiecznym, wskazującym na poważny kryzys $\mathrm{w}$ związku, a nawet zaburzenia psychiczne osób w nią zaangażowanych. W perspektywie uczestników jest fantazją, niekiedy realizacją istotnych pragnień seksualnych. Warto zaznaczyć, że na forum dominuje perspektywa uczestnika praktyk seksualnych. Jego treścią nie są deklaracje wywołane „sztuczną" sytuacją badania opinii społecznej na temat seksualności, ale realne odnoszenie się do postrzeganych subiektywnie problemów oraz wymiany własnych doświadczeń. Fora tego typu wydają się szczególnie interesującym miejscem, w którym można zapoznać się z faktyczną oceną i realizacją zachowań seksualnych. Na forum zauważane jest również ryzyko tego typu relacji, przy czym źródłem ryzyka zdaje się nie samo zachowanie, lecz internalizacja kulturowych kodów małżeństwa romantycznego, silnie nasyconego wyłącznością i emocjonalnością. Z tej perspektywy zdrada jest uznawana za zachowanie łamiące ustalony porządek małżeński społeczeństwa.

Każda z przywołanych przeze mnie na początku opracowania kultur seksualnych odnosi się do zdrady inaczej. W kulturze religijnej zdrada ma jednoznacznie negatywne konotacje moralne, jest grzeszna, tak samo jak aktywność seksualna poza związkiem małżeńskim. W kulturze seksuologicznej zdrada również wywołuje negatywne konsekwencje dla trwałości związku. W tym kontekście przywołuje się różne koncepcje próbujące wyjaśnić przyczyny dość jednak powszechnej pozamałżeńskiej aktywności seksualnej, zarówno kobiet, jak i mężczyzn. Koncepcje psychologiczne zawierają uzasadnienie odnoszące się do różnicy w potrzebach emocjonalnych i seksualnych kobiet i mężczyzn. Dla mężczyzn aktywność seksualna ma być oddzielona od emocjonalności, z kolei u kobiet obie sfery mają być ściśle połączone. Socjobiologiczne koncepcje zdrady wskazują na biologiczne przyczyny zdrady. „Samolubny gen”, dążący do reprodukowania się, nieświadomie kieruje zachowaniami mężczyzn, prowadząc ich do podejmowania aktywności seksualnej z wieloma kobietami. Kobiety natomiast inwestują swój potencjał genetyczny w dziecko, pragnąc mężczyzny zapewniającego dla niego opiekę i bezpieczeństwo. Socjologowie rodziny wskazują także na powszechność zdrady wśród współczesnych małżeństw, zaznaczając ponadto, że zdrada częściej bywa przyczyną rozwodów w klasach niższych.

W obrębie kultury indywidualizowania seksualności, czego przykładem jest cuckold, zdrada jest fantazją i niekiedy jej realizacją, jest formą gry/zabawy w odgrywanie dostępnych społecznie ról hotki, rogacza i kochanka. Obrazuje to zatem zachodzącą w kulturze współczesnej zmianę postrzegania i doświadczania seksualności.

Wreszcie zdrada kontrolowana może być także odbiciem zjawiska wzrastającej świadomości seksualnej kobiet oraz wiążących się z tym zwiększonych oczekiwań 
seksualnych wobec mężczyzn. Nawet jeśli kobiety powszechnie tego przekonania nie podzielają, co może być skutkiem rozpowszechniania w mass mediach mitu miłości romantycznej, do którego socjalizowane są kobiety, to część mężczyzn rozpoznaje tę zmianę i próbuje na nią reagować. Proces ten jest dodatkowo wzmacniany przez reklamy środków na potencję dla mężczyzn, sugerujących, że jednym z najważniejszych mierników spełnienia roli współczesnego mężczyzny jest nieustająca gotowość do odbycia stosunku seksualnego. Odzwierciedlenie wyobrażonych oczekiwań kobiety wobec mężczyzny może być więc kulturowym źródłem zachowań męskich realizowanych $\mathrm{w}$ roli rogacza. $\mathrm{Z}$ tego punktu widzenia rola „świadomie zdradzanego” może pełnić funkcję realizacji oczekiwanego zachowania mężczyzny dostarczającego przyjemności seksualnej kobiecie, nawet w sposób zapośredniczony przez inną osobę.

Sam akt „zdrady kontrolowanej” może być też męskim studium kobiecej przyjemności seksualnej. Oglądanie kobiety podczas kontaktu seksualnego z innym mężczyzną, realizowanie jej fantazji seksualnych, a jednocześnie zachowanie kontroli nad całym procesem (nawet jeśli jest ona niekiedy iluzoryczna) może także pełnić funkcję seksuologicznego dążenia do odkrycia tajemnicy kobiecego przeżywania przyjemności seksualnej i orgazmu, prowadzonej oczywiście w ramach kulturowych męskiej wyobraźni na temat doświadczania przyjemności.

Zdrada kontrolowana może być zatem interpretowana wielorako. Przyczyny i konsekwencje tego zjawiska, w zależności od przyjętej perspektywy postrzegania zachowań seksualnych, są odmienne. Z pewnością jednak „zdrada kontrolowana” jest przykładem zjawiska kulturowej transgresji seksualnej wysyconej „męskimi” wartościami i prowokuje do stawiania pytań na temat kształtu i znaczenia współczesnej seksualności oraz wpływu kultury na jej definiowanie i przeżywanie.

\section{Bibliografia}

Brown P. (2006), Ciało i społeczeństwo. Mężczyźni, kobiety i abstynencja seksualna we wczesnym chrześcijaństwie, przeł. I. Kania, Kraków.

Buczkowski A. (2016), Ciało, seksualność, indywidualizacja, [w:] Trickster. Społeczno-kulturowe konteksty doświadczania ciała, red. D. Majka-Rostek et al., Gdańsk.

Foucault M. (1995), Historia seksualności, przeł. B. Banasiak, T. Komendant, K. Matuszewski, Warszawa.

Friedman D. (2003), Pan niepokorny: kulturowa historia penisa, przeł. J. Kolczyńska, Warszawa.

Giddens A. (2006), Przemiany intymności. Seksualność, miłość i erotyzm we współczesnych społeczeństwach, przeł. A. Szulżycka, Warszawa.

Kinsey A.C. (1965), Sexual Behavior in the Human Female, New York.

Kinsey A.C., Pomeroy W.B., Martin C.E. (1948), Sexual Behavior in the Human Male, Philadelphia-London.

Kowalczyk R., Ciesielska B. (2010), Zaburzenia preferencji seksualnych (parafilie), [w:] Podstawy seksuologii, red. Z. Lew-Starowicz, V. Skrzypulec, Warszawa.

Lew-Starowicz Z. (2010), Seksuologia sądowa, Warszawa.

Masters W.H., Johnson V.E. (1975), Współżycie seksualne człowieka, przeł. R. Klimek, Warszawa. 
Tin L.G. (2013), Poczatki kultury heteroseksualnej w cywilizacji Zachodu, przeł. O. Hedemann, Kraków.

Wisłocka M. (1978), Sztuka kochania, Warszawa.

Zielińska I. (2015), Panika moralna. Homoseksualność w dyskursach medialnych, Kraków

Zimbardo Ph.G., Coulombe N.S. (2015), Gdzie ci mężczyźni, przeł. M. Guzowska, Warszawa.

\section{Źródła internetowe}

www1: http://dziendobry.tvn.pl/wideo,2064,n/zdrada-kontrolowana-czyli-zdrada-za-przyzwoleniem, 222787.html (dostęp: 28.02.2017).

www2: https://www.cuckoldplace.pl/topic/6284-wybierz-poprawnie-swoje-preferencje/?p=69361 (dostęp: 28.02.2017).

www3: https://www.cuckoldplace.pl/topic/23753-stop-zabawa/ (dostęp: 28.02.2017).

www4: http://www.logo24.pl/Logo24/10,136836,21257108, chce-z-zona-sprobowac-zdrady-kontrolowanej-seksuolozka-to.html (dostęp: 28.02.2017).

www5: http://www.cuckoldplace.pl/topic/4981-kodeks-ogiera (dostęp: 28.02.2017).

\section{The phenomenon of "cuckold" as an example of cultural sexual non-conformity}

\section{Summary}

This article considers the phenomenon of cuckold as an example of cultural transformations of sexuality in the Western culture. Author distinguishes three sexual cultures: religious, sexological and individualistic. Each of the sexual culture defines the cuckold in different way. Moreover the author analyses the content of internet group focused on cuckold in Poland as an example of individualistic sexual culture. 